\title{
Synaptic localization of striatal NMDA, quisqualate and kainate receptors
}

\author{
J. Timothy Greenamyre and Anne B. Young \\ Department of Neurology, University of Michigan, Neuroscience Laboratory Building, Ann Arbor, MI \\ 48104 (U.S.A.)
}

(Received 6 January 1989; Revised version received 22 February 1989; Accepted 22 February 1989)

Key words: N-Methyl-D-aspartate receptor; Quisqualate receptor; Kainate receptor

Striatal binding of labeled glutamate to $N$-methyl-D-aspartate (NMDA) receptors, D,L- $\alpha$-amino-3-hydroxy-5-methyl-4-isoxazoleproprionic acid (AMPA) to quisqualate receptors and kainate to kainate receptors was examined in rats which had received unilateral decortications or unilateral striatal quinolinic acid lesions. One week after decortication, there were no significant changes in NMDA, quisqualate or kainate receptors in the striatum ipsilateral to the lesion, when compared to the striatum contralateral to the lesion. In contrast, binding to NMDA receptors was reduced by $92 \%$, to quisqualate receptors by $80 \%$ and to kainate receptors by $81 \%$ in striatum 3 months after quinolinic acid lesions. The reduction in NMDA receptor binding was significantly greater than the loss of quisqualate or kainate receptors. These results suggest that NMDA, quisqualate and kainate receptor recognition sites are located postsynaptically in the striatum. These results also have implications for the quinolinic acid model of Huntington's disease.

Excitatory amino acids exert their actions through at least 3 distinct receptor types, named for $N$-methyl-D-aspartate (NMDA), quisqualate and kainate [14]. The majority of each of these receptor types appears to be located postsynaptically on dendrites or somata. Although somewhat controversial, it has been suggested that there are sub-populations of presynaptic NMDA [3, 5, 10], quisqualate [4] and kainate receptors [6]. The current study was undertaken to help clarify the synaptic localization of striatal NMDA, quisqualate and kainate receptors.

Male Sprague-Dawley rats (200-230 g) were anesthetized and positioned in a Kopf stereotaxic frame. Unilateral striatal lesions were made with quinolinic acid at a dose of $60 \mathrm{nmol}$ at uniform stereotaxic coordinates ( $1 \mathrm{~mm}$ anterior to bregma, 2.5 $\mathrm{mm}$ lateral to bregma and $5 \mathrm{~mm}$ deep from the cortical surface). Quinolinic acid was dissolved in $0.1 \mathrm{M}$ phosphate buffer ( $\mathrm{pH} 7.4$ ) and injected in $0.5-1.0 \mu \mathrm{l}$ via a Hamilton syringe over a period of $8 \mathrm{~min}$. After injection, the syringe was left in place for $5 \mathrm{~min}$ prior to withdrawal. Animals with striatal lesions were allowed to survive for

Correspondence: A.B. Young, Department of Neurology, University of Michigan, Neuroscience Laboratory Building, 1103 East Huron, Ann Arbor, MI 48104, U.S.A. 
3 months prior to sacrifice. For decortications, a dental drill was used to make a skull flap from about $3 \mathrm{~mm}$ posterior to $6 \mathrm{~mm}$ anterior to bregma, and $2 \mathrm{~mm}$ lateral to the mid-line to the lateral edge of the calvarium. After removal of the skull flap, the underlying cortex was removed by aspiration and cortex lateral to the opening in the skull was undercut with a suture needle. One week after lesioning, the animals were sacrificed and the brains prepared for assay.

Twenty $\mu \mathrm{m}$ tissue sections were thaw-mounted on gelatin-coated slides. Sections received a $30 \mathrm{~min}$ wash in ice-cold $50 \mathrm{mM}$ Tris-acetate buffer $(\mathrm{pH} \mathrm{7.20)}$ to remove endogenous excitatory amino acids. For NMDA receptor assays, tissue sections were incubated in $50 \mathrm{mM}$ Tris-acetate buffer $(\mathrm{pH} \mathrm{7.20)}$ at $2 \mathrm{C}$ for $45 \mathrm{~min}$ in the presence of $28 \mathrm{nM}$ labeled L-glutamate. The incubation buffer contained $1 \mu \mathrm{M}$ quisqualate and $1 \mu \mathrm{M}$ kainate to block binding to those receptor types. NMDA $(1 \mathrm{mM})$ was used to define non-specific binding. Quisqualate receptors were assayed by binding of AMPA in $50 \mathrm{mM}$ Tris- $\mathrm{HCl}$ buffer containing $2.5 \mathrm{mM}$ calcium chloride and $100 \mathrm{mM}$ potassium thiocyanate. Non-specific binding was determined in the presence of $1 \mathrm{mM}$ unlabeled glutamate. Kainate receptors were labeled with $\left[{ }^{3} \mathrm{H}\right] \mathrm{kainic}$ acid in $50 \mathrm{mM}$ Tris-acetate buffer ( $\mathrm{pH} 7.20$ ). Non-specific binding was measured in the presence of $1 \mathrm{mM}$ unlabeled glutamate. For all of the assays, tissue sections were incubated for $45 \mathrm{~min}$ at $2^{\prime \prime} \mathrm{C}$. At the end of the incubation, sections received 3 quick rinses with ice-cold $50 \mathrm{mM}$ Tris-acetate buffer followed by 2 quick rinses with cold $2.5 \%$ glutaraldehyde in acetone. Sections were blown dry under a stream of warm air. The total time from the end of the incubation until the slides were dried was $10 \mathrm{~s}$. Dried sections were placed in X-ray cassettes along with appropriate radioactive standards and were exposed to tritium-sensitive Hyperfilm (Amersham) for 23 weeks. The film was then developed, fixed and dried. Resultant autoradiograms were analyzed using an MCID image processing system (Imaging Research, Inc., St. Catharine's, Ont., Canada). Serial sections from 3 decorticate and 3 striatal-lesioned rats were assayed and analyzed for NMDA, quisqualate and kainate receptors. In both sets of animals, binding in the striatum contralateral to the lesion served as the control [9]. In decorticate animals, dorsolateral portions of the striatum were analyzed for receptor binding. After quinolinate lesions, binding was measured in the central portions of the lesion and in corresponding areas of the contralateral striatum. Binding ipsilateral to the lesion was compared with contralateral binding by paired $t$-test.

Receptor binding was studied one week after decortication because studies of high affinity glutamate uptake, a presynaptic marker, show large decreases 1-2 weeks after decortication $[9,13]$. Our use of the contralateral striatum as a control after decortication may have resulted in a slight underestimation of any subsequent receptor changes, because there may be a small crossed corticostriatal projection. However, similar use of the contralateral striatum as a control still results in a $40-55 \%$ decrease in presynaptic glutamatergic markers ipsilateral to the lesion $[9,13]$.

Following unilateral decortication, there were no significant asymmetries in strialal binding to NMDA, quisqualate or kainate receptors (Figs. 1 and 2). Although the binding of kainate was reduced to $83 \pm 3 \%$ ipsilateral to the lesion, this did not reach statistical significance by paired $t$-test. 

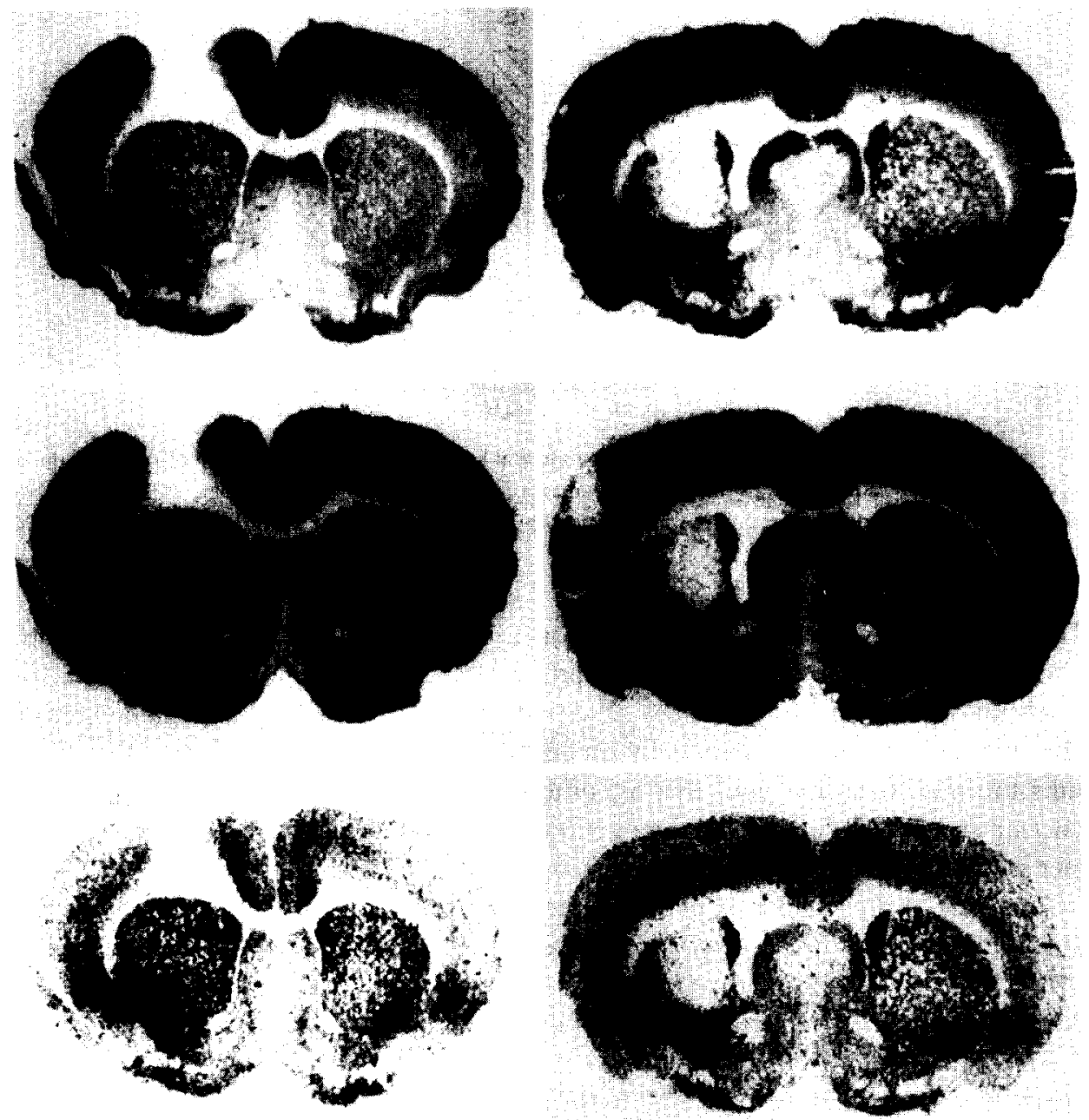

Fig. 1. Autoradiograms of binding to NMDA receptors (top), quisqualate receptors (center) and kainate receptors (bottom) in serial sections from rats with unilateral frontoparietal decortication (left) and unilateral striatal quinolinate lesions (right). See text and Fig. 2.

After striatal quinolinate lesions, NMDA receptor binding was reduced by $92 \%$. Quisqualate and kainate receptors were reduced by $80 \%$ and $81 \%$, respectively. Analysis of variance indicated that the loss of NMDA receptors was significantly greater than the loss of quisqualate or kainate receptors $(P<0.05$, ANOVA with NewmanKeuls test).

The results of this study indicate that the majority of striatal NMDA, quisqualate and kainate receptors are located postsynaptically. Based on excitatory amino acid release studies, it has been postulated that presynaptic NMDA receptors exist in the olfactory tract [3], and hippocampus [5]. Furthermore, binding studies suggest the presence of presynaptic NMDA receptors on the granule cells of the cerebellum [10]. 


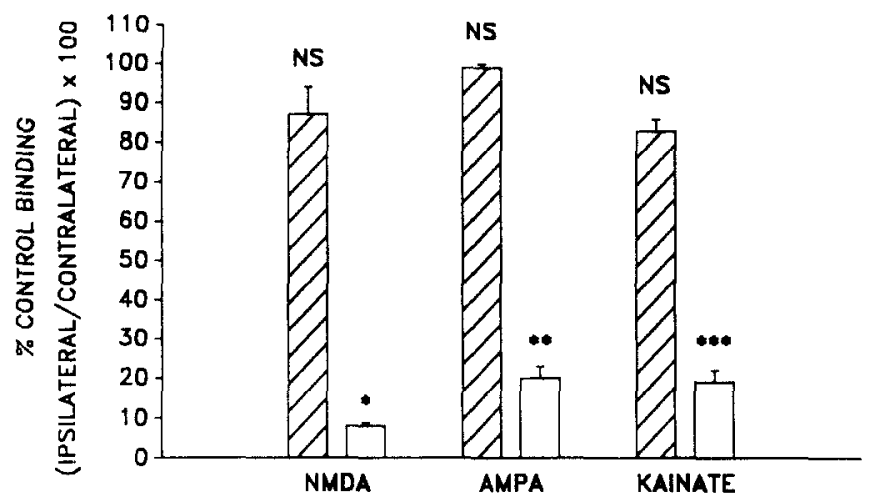

Fig. 2. Histograms of binding to NMDA, quisqualate and kainate receptors in striatum of rats with unilateral decortication (striped bars) and unilateral striatal quinolinate lesions (open bars). Percent control binding is expressed relative to binding in the striatum contralateral to the lesion. ${ }^{*} P<0.05 ; * * P<0.04$; *** $P<0.02$; NS, not significant.

The current study does not provide support for the notion that there are presynaptic NMDA receptors on the glutamatergic afferents to the striatum.

Although a recent study has suggested that up to $30 \%$ of striatal quisqualate receptors may be located presynaptically on corticostriatal afferent terminals [4], our results are not consistent with this hypothesis. The reasons for this discrepancy are unclear and may reflect subtle damage to the striatum from decortication in the former study, or differences in assay conditions.

The issue of presynaptic kainate receptors has been controversial $[6,7]$ and previous binding studies in the cerebellum have not provided support for this hypothesis [10]. However, two previous binding studies in homogenate preparations have demonstrated small reductions in striatal kainate receptor binding after unilateral decortication $[2,8]$. In this study, we have observed a small (17\%) but consistent decrease in kainate binding ipsilateral to the decortication, but this did not reach statistical significance by paired $t$-test. The failure to reach significance may have been influenced by the small contralateral corticostriatal projection which might cause a slight contralateral decrease in binding as well. Nevertheless, we cannot entirely rule out the possibility that there is a small population of presynaptic kainate receptors located on corticostriatal afferents.

Recently, quinolinic acid lesions of the striatum have been proposed as a relatively accurate model for Huntington's disease $[1,11]$. Because quinolinate acts at the NMDA receptor [12]. it has been suggested that excitotoxicity at this receptor may play a role in the pathogenesis of Huntington's disease. Consistent with this hypothesis, we have recently reported a $93 \%$ reduction in NMDA receptors in the putamen of Huntington's disease patients; the loss of NMDA receptors was significantly greater than that of quisqualate receptors [15]. The current demonstration of a $92 \%$ reduction in NMDA receptors, together with the fact that this reduction is significantly greater than that of quisqualate receptors, provides further support for the quinolinate striatal lesion model of Huntington's disease. 


\section{Supported by USPHS Grant AG 06155 and the Arbogast Foundation.}

1 Beal, M.F., Kowall, N.W., Ellison, D.W., Mazurek, M.F., Swartz, K.J. and Martin, J.B., Replication of the neurochemical characteristics of Huntington's disease by quinolinic acid, Nature (Lond.), 321 (1986) 168-171.

2 Biziere, K. and Coyle, J.T., Effects of cortical ablation on the neurotoxicity and receptor binding of kainic acid in striatum, J. Neurosci. Res., 4 (1979) 383--398.

3 Collins, G.G.S., Anson, J. and Surtees, L., Presynaptic kainate and $N$-methyl-D-aspartate receptors regulate excitatory amino acid release in the olfactory cortex, Brain Res., 265 (1983) $157-159$.

4 Erram, M. and Nieoullon, A., Alpha-[ $\left.{ }^{3} \mathrm{H}\right]$ amino-3-hydroxy-5-methyl-4-isoxazoleproprionic acid binding to rat striatal membranes: effects of selective brain lesions, J. Neurochem., 51 (1988) $579 \ldots 86$.

5 Errington, M.L., Lynch, M.A. and Bliss, T.V.P., Long-term potentiation in the dentate gyrus: induction and increased glutamate release are blocked by $\mathrm{D}(-)$ aminophosphonovalerate, Neuroscience, 20 (1987) 279284.

6 Ferkany, J.W. and Coyle, J.T., Kainic acid selectively stimulates excitatory amino acid neurotransmitter release at presynaptic receptors, Nature (Lond.), 298 (1982) 757-759.

7 Garthwaite, J. and Garthwaite, G., The mechanism of kainic acid neurotoxicity, Nature (Lond.), 305 (1983) 138-140.

8 Henke. H. and Cuenod, M., L-Glutamate specific $\left[{ }^{3} \mathrm{H}\right] \mathrm{kainic}$ acid binding in the rat neostriatum after degeneration of the corticostriatal pathway, Neurosci. Lett., 11 (1979) 34l-345.

9 McGeer, P.L., McGeer, E.G., Scherer, U. and Singh, K., A glutamatergic corticostriatal path?, Brain Res., 128 (I977) 369-373.

10 Olson, J.M.M., Greenamyre, J.T., Penney, J.B. and Young, A.B., Autoradiographic localization of cerebellar excitatory amino acid binding sites in the mouse, Neuroscience, 22 (1987) 913-923.

11 Schwarcz, R., Foster, A.C., French, E.D., Whetsell, W.O., Jr. and Kohler, C., Excitotoxic models for neurodegenerative disorders, Life Sci., 35 (1984) 19-32.

12 Stone, T.W. and Connick, J.H., Quinulinic acid and other kynurenines in the central nervous system, Neuroscience, 15 (1985) 597-617.

13 Walker, J.E. and Fonnum, F., Effect of regional cortical ablations on high affinity D-aspartate uptake in striatum, olfactory tubercle, and pyriform cortex of the rat, Brain Res., 278 (1983) 283-286.

14 Watkins, J.C. and Evans, R.H., Excitatory amino acid transmitters, Annu. Rev. Pharmacol. Toxicol., 21 (1981) 165-204.

15 Young. A.B., Greenamyre, J.T., Hollingsworth, Z., Albin, R., D'Amato, C., Shoulson, I. and Penney, J.B., NMDA receptor losses in putamen from patients with Huntington's disease, Science, 241 (1988) 981-988. 